\title{
Brazil’s Indigenous Peoples and Their Autobiographical Narratives
}

\author{
Suzane Lima Costa \\ Universidade Federal da Bahia (UFBA), Bahia, Brazil
}

\begin{abstract}
When considering indigenous people in Brazil, both in academic and non-academic settings, the individuals' names are almost always ignored for the sake of representing their collectivity as communities, as Peoples. Discussing autobiographies or indigenous biographies is still an uncommon endeavor, even in our field of Letters/Liberal Arts or in Indigenous Ethnology. However, since the beginning of the process of reclaiming the lands that once belonged to them, the indigenous Peoples have been producing autobiographical narratives, demonstrating how this genre of text production—-traditionally linked to the development of the Western individual—can constitute and be appropriated in different Amerindian translations. It is from this perspective that I intend to present a discussion about those text productions, analyzing what their collective signatures express, and how their proper names are constructed and signified on behalf of the group.
\end{abstract}

Keywords: indigenous people, autobiography, memory, identity

\section{Introduction}

When considering the indigenous in Brazil, both in academic and non-academic settings, the individuals' names are almost always ignored for the sake of representing their collectivity as communities, as Peoples (as in nations or tribes). Discussing autobiographies or indigenous biographies is still an uncommon endeavor, even in our field of Letters/Liberal Arts or in Indigenous Ethnology. As he considered this theme in the article “Autobiografia e sujeito indígena” (Autobiography and the Historic Indigenous Subject), Oscar Sáez (2006) defended the thesis that the autobiography, a central genre in the written bibliography for or about the indigenous population in the United States is non-existent in the equivalent bibliography in Brazil. Sáez (2006) questions the reasons for this contrast by analyzing how the entry "autobiography" simply does not appear in the bibliographical repertoires of the Brazilian ethnology.

A considerable share of the debates that involve narratives, self and the indigenous centralize the myth and history of each People, but, "it seems that, a Brazilian indigenous never decided or was requested to provide an account of their own lives, instead of reporting on the myth or the history of their people” (Sáez, 2006, p. 181). From the perspective brought by the author, what does that absence mean? Does it mean to say that the indigenous should always be thought of as a collective, as if their "self" did not have a place in the narratives that self-represent their group? Or that the indigenous discourses tend to discredit the individualistic illusion, as it dissolves the "self" into the signature of the "Tupinambá's People”, the "Tuxá People”, the "Kuikuro People", the "Pataxó People”?

Suzane Lima Costa, Ph.D. in Theory and Criticism of Literature and Culture, Adjunct Professor at Universidade Federal da Bahia. 
By raising those questions, I conducted, in partnership with the researchers ${ }^{1}$ of the Núcleo de Estudos das Produções Autorais Indígenas-NEAI (Indigenous Authorship Productions Study Center), a survey on the indigenous authorial production, which has been published on the internet or in the Brazilian publishing industry in the past fifteen years. I found a significant number of indigenous narratives collectively signed and narrated, or written in first person, or in co-authorship with their editors. Those productions appear in different supports and text genres, like videos, textbooks, chronicles, “anecdotes”, poems, e-mails, public announcements, interviews, end-of-term monographs and letters written by the indigenous addressed to Brazil ${ }^{2}$. A significant sample of those writing practices are present in the book collections Índiosnavisão dos índios (Indians Through the Eyes of Indians), organized by Thydêwá; ${ }^{3}$ Cineastas Indígenas (Indigenous Movie Makers), organized by the project Vídeosnas Aldeias ${ }^{4}$ (Videos in the Villages); and Narradores Indígenas do Rio Negro (Indigenous Narrators of Rio Negro), produced by FOIRN_Federação das Organizações Indígenas do Rio Negro ${ }^{5}$ (Federation of the Indigenous Narrators of Rio Negro). Not to mention the over thirty authorship productions, which do not have a great circulation, but can be found on the Literaterras Center website ${ }^{6}$.

I also highlight here the written productions by a single author, but focused, generally, on narratives of the myth or the history of the People, as the novels by Daniel Munduruku, the works of Olívio Jecupé, Eliane Potiguara, Graça Graúna, among others. Also aware of this panorama, Saéz (2006) emphasizes that if one expects from a biography to know, above anything else, who the narrator is in his/her own terms, "in the indigenous narratives we have then an extrospection of 'self', instead of an introspection” (Saéz, 2006, p. 187). It is in this sense that the indigenous narratives present challenges to the notion of the autobiographical genre itself, simply due to including the narrative person who destabilizes the idea of self in itself, by recognizing himself/herself as a plural author, but without making it evident that, in the process, other personas are created.

\footnotetext{
1 The researcher Rafael Xucuru-Kariri, Master in Social Sciences and analyst of public politics for MEC (Ministry of Education), and the MA candidates Thaiane Pinheiro, Iranildes Aquino and Francielle Santos (UFBA), participate directly in the project "Indigenous (Auto)biographies", developed as part of the NEAI activities, at Bahia Federal University. NEAI started its activities in 2010, with the general objective of producing and circulate biographical productions by the indigenous in Brazil, as well as analyze and discuss the authorial emergence of the historic indigenous subject politically and literarily in Brazil, also having as one of its specific objectives the publication of a book collection named Letters from the Indigenous People to Brazil (Project funded by CNPq — National Counsel of Technological and Scientific Development).

${ }^{2}$ With the project Letters from the Indigenous Peoples to Brazil (CNPq), we aim to build the record of letters produced by indigenous peoples in Brazil, which circulate with wide repercussion on social networks and on the news both inside Brazil and abroad, as well as the letters that, out of the virtual world, were written and sent to the Federal Government and to the international organizations, since the approval of the indigenous rights in the 1988 Constitution up to the present date. As one of the final results of this work, we intend to publish a book collection called Letters from the Indigenous Peoples to Brazil, and advocate for its use in elementary and middle public schools.

3 Thydêwá is a non-governmental organization formalized in 2002, which acts, mainly, in the northeast of Brazil. They develop educational projects of various ethnicities and nations, by means of workshops at the indigenous villages, enabling them to work as researchers, documentarists, journalists, historians, anthropologists, poets, philosophers and photographers of their own realities, having as outcome the collection Índiosnavisão dos Índios (Indians Through the Eyes of Indians). For further information, visit the website from http://www.thydewa.org/work/indios-na-visao-dos-indios. Retrieved on 15th September 2015.

${ }^{4}$ Videos in the Villages is a project in the field of indigenous audiovisual production in Brazil, created in 1986. Since 2000, the collection Indigenous Film Makers, outcome of the video production workshops in the villages, is distributed free of charge to schools, associations and indigenous communities and to non-indigenous high schools. For further information, visit the website http://www.videonasaldeias.org.br. Retrieved on 15th September 2015.

${ }^{5}$ The edition is made possible by two indigenous organizations, the Federation of Indigenous Organizations of Rio Negro (FOIRN) and the União das Nações Indígenas do Rio Uaupés Acima (The Union of the Indigenous Nations of Uaupés Acima River) (UNIRVA), and for the Socio-environmental Institute (ISA). Up to now, eight issues have been published.

6 To learn more about those works visit the Literaterras Center, retrieved 15th September 2015 from https://literaterras.wordpress.com/publicacoes/autoria-indigena.
} 
There is a long debate concerning the paradigm shift in the construction of the autobiography concept, propelled by the new subjectivities which fissure the discourse on stable and univocal selves, typical of traditional autobiographical models, by believing beyond a multiple conception in the montages of "self", the writings of political minorities which narrate their histories as a type of re-existence.

Thinking about this discussion I decided to investigate the absence suggested by Saéz (2006) to elucidate how the indigenous put together the accounts of their lives and, this way, propose a research project that might present, with their proper names, Mario Juruna, Galdino Hã-Hã-Hãe, Zabelé Pataxó, Marcelino Tupinambá, Quitéria Binga, Chicão Xucuru, Babau Tupinambá, Maria Pankararu, Maninha Xucuru-Kariri, Rita Potiguara and many others, in their day-to-day lives, in their manner of doing things, of being, of eating, of loving, of acting in the world. I started to consider if the exercise of biographing their life histories could be a way of making the name of an indigenous person matter, without emptying its collective place of existence, but thinking of it, questioning Deleuze (2006), without losing sight of his/her face. This issue prompted two other questions: how is the "who" constituted under the umbrella of the "Indian" signature of the Kuikuro People, the Guarani People, the Pataxó People, the Truká People, among others? How can one, considering the very meaning of the question about who you are, prioritize the accounts of the life of those individuals who have never had their names written in the parallax of the great history?

Those questions formatted the investigative itineraries of the research project named Indigenous (Auto)biographies, and worked as the starting point for discussing how those people, while narrating themselves, project a revision of the notion of person and the notion of autobiography itself. In order to do so, I considered, from the gathered corpus, three perspectives related to the notion of autobiographies proper of the manner of narrating of the indigenous: (1) The autobiographies without a proper name, when the narratives are produced on behalf of the collective and interweaved with individual histories; (2) The extrospective autobiographies, when the narrative of self does not narrate an intimate-self, but the mythical/historic one; (3) The autobiographies of the enchanted, when the indigenous give the credit of the authorship of their narratives to the spirit of the forests.

Even if it is only to present preliminary reflections on an ongoing research, I am going to address here each of those points, without the pretension of covering all there is to be said or separating them to apply each type of writing, but acknowledging their overlaps and differences in some works of the collection named Indians Through the Eyes of Indians (2008, 2003, 2012), with the focus on the narrative of the Tupinambá, and the work Tradição Pankararé: a festa do Amaro (Pankararé Tradition: Amaro’s Festival) (2007).

\section{From the Collective Autobiographies to the Extrospective Autobiographies}

The collection Indians Through the Eyes of Indians presents different indigenous peoples, geopolitically situated in the northeast of Brazil, narrating in chants, "anecdotes”, testimonials, photographs and drawings their life histories. Those productions tell the history of each people, overlapping their narratives of foundation with brief pieces of information on the ethnic identities. Up to now, there is a printed version of twenty works that describe the life of the Truká, the Tumbalalá, the Tupinambá, the Kiriri, the Pataxó Hã-Hã-Hãe, the Kariri-Xocó, the Fulni-ô, the Pataxó do Prado, the Pankararu and the Potiguara. The works present on each cover the title Indians Through the Eyes of Indians and bring, as a subtitle, the name of the ethnic group that is to be presented. On the back covers of the history of each indigenous People, we can see standing out, changing only the name of each ethnic group, the following assertive: "The People of the nation (name of the People) is the true 
author of this book. The texts, the photographs, the drawings and the final art services were done by the Indians themselves”. The six covers below are examples in the illustrated part of that work (see Figure 1). ${ }^{7}$
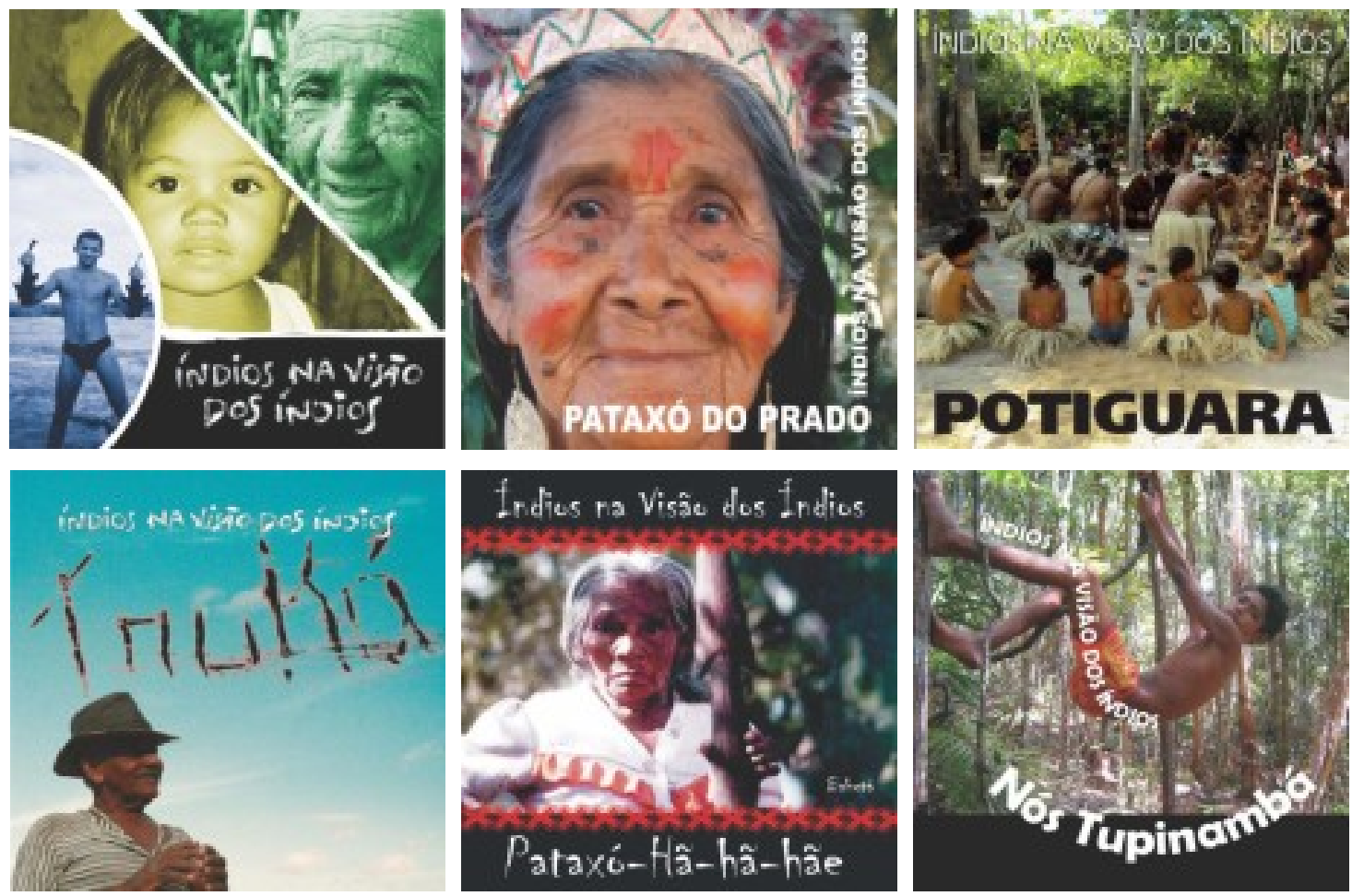

Figure 1. Covers of the books. ${ }^{8}$

Nhenety Kariri-Xocó (Alagoas), Dora Pankararu (Pernambuco), Manuel Monteiro da Luz Pankararu (Pernambuco), Nailton Pataxó (Bahia), Anaiá Tupinambá (Bahia), Antonio Cícero da Silva Truká (Pernambuco), Katu Tupinambá (Bahia), Antonio e Dona Lurdes Truká (Pernambuco) and Maria Pankararu (Pernambuco) are some of the proper names that are present at the end of each transcribed excerpt, of each testimonial, of each narrated history. Also in the acknowledgements, on the back covers, some names of members of the community who collaborated with the creation of the works. ${ }^{9}$ Thus, the question about the name of each indigenous person is still more encompassing in meaning when the singular-self appears in the extension of the collective history, presenting his/her proper name in the sequence of we, which contextualizes its place of belonging in the group, for instance, in the narrative of Mr. Nailton Pataxó:

My name is Nailton Muniz Pataxó, from the Tupinambá Ethnicity. I am one of the Chiefs here in the Caramuru Indigenous Land-Catarina Paraguaçu, I live here with the PATAXÓ HÃHÃHÃE People. My grandfather was Tupinambá from Olivença and I was born at Queimado Farm, in the Ourinho region, in the county Pau Brasil. The staff of SPI-Serviço de Proteçãoao Índio (Indian Protection Service) sold and split our territory and we started to suffer a lot, having to leave our lands. In 1975, they elected me as one the leaderships to work for the relatives that were inside the indigenous area and also to bring back those who were out. (Povo Pataxó Hãhãhãe, 2007, p. 24)

\footnotetext{
7 All of the twenty book covers, as well as the complete works are available for download on the website: http://www.thydewa.org/downloads1. Retrieved on 15th September, 2015.

8 Source: Thydêwá. Retrieved 15th September 2015 from http://www.thydewa.org/downloads1.

9 The collection Indians Through the Eyes of Indians is produced in the artistic creations workshops, coordinated by the anthropologist Sebastián Gerlic and by Maria Pankararu, and held in the indigenous villages of the northeast, with wide participation of members of the community.
} 
This is exactly the point that singularizes the collections: the People, in its ethnic name, reporting the history of the community and the proper name of each indigenous, presented as flashbacks of the collective memory. Also, this singularity is what the editor, in this case, the anthropologist Sebástian Gerlic, makes the textinto, as he removes it from the oral narratives, from the workshop of creation of the book, cutting and pasting the vision of the community, in partnership with the indigenous that participate in the whole process of assembling the final work delivered to the public ${ }^{10}$. Each autobiographical narrative, presented in those twenty works, also represents the need of re-existing of each People, through the intensification of the processes of revisiting oneself and the way of doing things in their collective authorial praxis.

The exercise of orally narrating one's own history, photographing or drawing the community and its members, is part of a political project that is strategically organized in the name of the People, without naming a specific author and without subordinating the autonarrative to the excessive search of a true self of who is writing. Thus, enquiring through whom, in the collection Indians Through the Eyes of Indians, means being opened to the history of the narrator, who in each work is named as the People of the nation, and, at the same time, opened to the different individual voices, which present their daily histories and their ways of re-existing to their rightful society. The construction of the author subject in the narratives is effective without the need of identifying the presence of the intimate-self, typical of traditional biographies, but, above all, understanding that all the language use can serve an autobiographical expression (Lejeune, 2013, p. 538). Therefore, the autobiographical narratives of the group are constructed without the linearity of each person's life history, but in snips, in lapses of memory, from the statement each one believes to be important to make about themselves.

In the autobiography of the Tupinambá ${ }^{11}$, for instance, I found it in the history of Joanilda Tupinambá, who carried, in her puny body, thirty and two kilos of piaçava, every day, in order to sell it in Olivença, Bahia, the closest city to her village; and in the interview given by Gilmar Tupinambá to Genilson, from the same ethnicity, about how he extracted piaçava. In the same book there is still the dream of Mr. Pinduca Tupinambá, the narrative of Araponga about the arrival of the white people, as well as the statement by Ms. Amotara explaining what it is like to be the midwife of the village:

I do not have a midwife diploma, but a gift already existed inside of me. I have the courage and I grab it. I know when it is late and I find a way to make things work. I talk to tupã, ask him for help and everything comes. I think I have held more than a hundred of them. (Tupinambá, 2003, p. 27)

With the same tone as Ms. Amotara's quick presentation of her work, I also found texts that defend the respect for the Indian and the right to own the land, without a proper name or reference to images, but, according to the warning highlighted with capital letters on the back cover of each book, authorship of the Tupinambá People. At the end of the Tupinambá's book, there are two handwritten letters explaining what it is to be an Indian, signed by Inaiá and Mboessara. There is no time sequence of the events, nor the presentation of

\footnotetext{
${ }^{10}$ I highlight here that, even considering that all the authorial process is related to the sociocultural praxis that results from collective actions, due to the dialogic/ intertextual/ polyphonic condition of any text in itself, it is not possible to ignore the need of a critical study on the existing relationship between the process of elaboration of those texts and the final work delivered to the public. That represents the need of re-existing of each people, through the intensification of the processes of return to self and the manner of doing things in their collective praxis.

${ }^{11}$ The Tupinambá live in the south of Bahia, to the north of Ilhéus City. Their territory encompasses from the coast of Olivença village to the Serra das Trempes (Sierra of Trempes) and Serra do Padeiro (Sierra of the Baker). Today, the village known as Olivença is the place where, in 1680, an indigenous village was founded by the Jesuit missionaries. To learn more, visit Tupinambá, from http://pib.socioambiental.org/pt/povo/tupinamba. Retrieved on 15th September, 2015.
} 
voices in a hierarchy. Therefore, there is no room for defense, as Lejeune once wished, in Le pacte autobiographique (Lejeune, 1975), the self-image of the real person, of the absolute self, as this self is always mediated, spaced, or even implicated, in the narrative us. Indeed, what we are presented with is a complex net of narrators that explain who they are through a continuous symbiosis between singularity and collectivity of belonging.

This way, the narrative exercise of the Tupinambá, similarly to how it is in the works of the Pataxó, Kiriri and Truká, is formed with fragments of self, in snips of collective conversations, shaped on each page, each workshop, each choice of images selected for the text or in each talk with the editor of the texts. It is like a cartography that this self-image formats. A cartography is built beyond the geographic meaning of maps which define territories, but, as Cesar (2011) proposes, like a kaleidoscopic composition of texts, in different genres and modalities. In this sense, cartography can encompass a set of interests, procedures and principles constituted by the contingency of time, language, and historic/mythical place of the subject who is speaking.

In addition to the works focused on the presentation of each People, the collection Indians Through the Eyes of Indians is constituted of groups of ethnicities who remember their mythical past and who present their autobiographies not by the introspection of self, but by its extrospective. The works named Cultura Viva (Living Culture) (2012), Memória (Memory) (2012) and Somos Patrimônio (We are Patrimony) (2011) are three of the nine productions that present those accounts. There is also the intent of presenting the histories of their rites, chants and dances, as well as the historic aspect of the contacts with the non-Indian.

The covers of the works, as illustrated below (see Figure 2), differently from the ones we saw in the previous images, do not refer to the names of each ethnic indigenous group as the author of the narrative. This indication is only made on the back covers, on behalf not of only one community, but of the collective interweaving that united different Peoples to celebrate their histories.
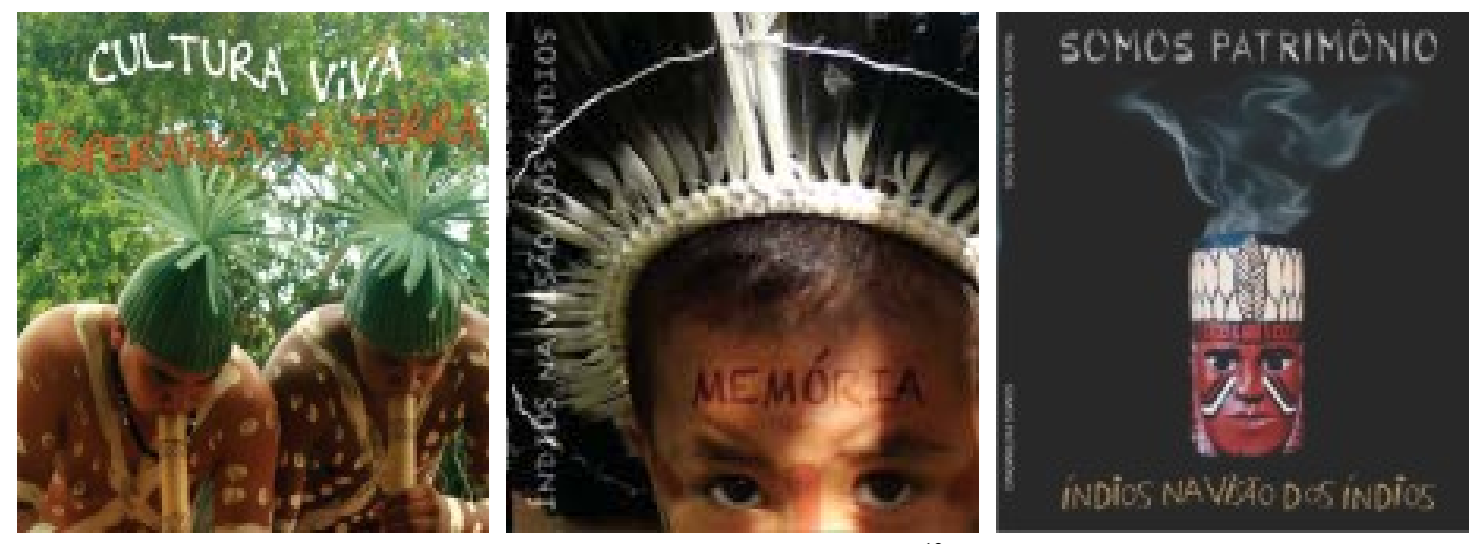

Figure 2. Covers of the books. ${ }^{12}$

In the Memoria (Memory) (2012), issue 17 of the collection, the Peoples of the ethnicities, Tubinambé, Kariri-xocó, Pataxó Hã-Hã-Hãe, Pataxó, karapató, Xocó and Pankararu, tell those narratives, returning to the past in their ways of reading the present through their portrayal of the individual self or the collective us. The history of the arrival of the Portuguese and the memories of the Tupinambá as original Peoples introduce the work, in Kaluanã Tupinambá's voice. After that, the historic and mythical self, which, according to Kaluanã, was enslaved and decimated by the Portuguese, reappeared in 1930, empowered in the actions of the

12 Source: Thydêwá. Retrieved 15th September 2015 from http://www.thydewa.org/downloads1. 
indigenous Marcelinos Tupinambá, considered an indigenous leader and defender of the Tupinambá lands during the Vargas Era. The Portuguese invasion narrative makes room for the history of the Rebellion of 1930 on Tupinambá lands, which was inspired by the biography of the Indian Marcelino Tupinambá, by the indigenous Katu and Carlos Tupinambá. The short autobiography Marcelino vive em nós (Marcelino Lives in Us) was constructed in two voices and presents Marcelino by returning to the history of fights for land demarcation, providing a snapshot of the Tupinambá's situation at the time.

In the recollection of the biographies of other indigenous to talk about themselves, in other words, in the extrospection of self to talk about historic facts of their People, there is a common background to the ways of narrating of the Tupinambá that repeats itself. Respecting their respective differences, in the narratives of the other indigenous Peoples in the northeast find a way to guarantee their own existence through a political and mystical reinvention of the us. That is why, in the end of the 21st century, nobody would discuss those people in their ethnic, cultural and historic distinctions, they were labeled as the mixed Indians, named as such by the local authorities of the time, by the regional population and by themselves. In this situation, their festivals, beliefs, myths and histories of life were taken as "popular traditions", not as indigenous traditions (Oliveira, 1998).

In the text Uma etnologia dos índios misturados (An Ethnology of the Mixed Indians) (1998), João Pacheco de Oliveira discusses the paradoxal paths related to the recent emergence of those "Peoples who are

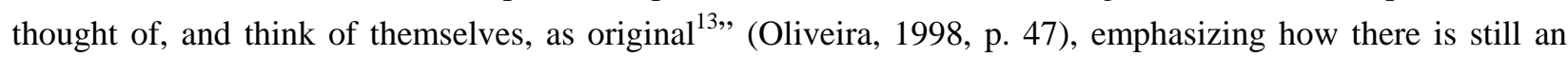
identity weight of "accultured", "mixed", that is, if not completely "without": without territory, without language, without cultural contrastivity (Oliveira, 1998). Silenced by the historiographies and seen as minor objects by traditional ethnography ${ }^{14}$, those people started to be described only through the accounts of the chroniclers of the 16th and 17th centuries or by the naturalistic travelers of the 18th and 19th centuries. In other words, they started being thought of "only as what they used to be, (or for what they suppose they were) centuries ago, but nothing (or very little) is known about what they are today” (Oliveira, 1998, p. 49).

In defense of their own histories and territory, constructing ways of guaranteeing their identity singularity/collectiveness in relation to the other groups, the indigenous in the northeast have been constructing responses to restate their ethnicity and their historic, linguistic and cultural patrimony, especially in the fight for demarcation of their lands and, consequently, for the continuity of their life histories. These answers are produced and put into circulation by a variety of groups cited here through the production of those self-representative narratives, inserted in defense of the collective identity of each People, language, and discourse of tradition.

The autobiographic writings which ratify these attempts of self-legitimation, and which are being partially presented here, are also elucidative of the ethnic emergence constructed by each People in defense of their

\footnotetext{
${ }^{13}$ For the anthropologist, what makes the matter even more complex are the similar conceptualizations of the idea of original Peoples as: aboriginal populations, in Australia, Oceania, Argentina and Canada; "autochthone populations", a typical idea of Frenchethnology, "first nations", employed by indigenous organizations in the United States. See Oliveira, João Pacheco from http://www.scielo.br/pdf/mana/v4n1/2426.pdf. Retrieved on 15th September, 2015.

${ }_{14}$ Oliveira (1998) defends the thesis that the two greatest branches of ethnological studies of the autochthonic populations in South America - the North-American cultural evolutionism and the French structuralism-for their theoretical and methodological principles in the development of researches in the field, contributed decisively to the construction of a negative evaluation concerning the perspectives of an ethnology of indigenous Peoples and cultures of the northeast. The same happened with the indigenism in Brazil. See: Oliveira, João Pacheco. For further exploration of the theme, visit from http://www.scielo.br/scielo.php?pid=S0104-93131998000100003\&script=sci_arttext. Retrieved on 15th September, 2015.
} 
identity as indigenous ${ }^{15}$. This way, the idea or returning to self, as a project of collective authorship of each People, encompasses both the emergence of other identities, as the reinvention of ethnicities already known, a matter that is fundamental to understand the political importance of the formation of a biographic space of the indigenous in the northeast of Brazil.

That is where comes the need to speak about oneself as a collective while reconstructing their mythical and historic past. The Kariri-Xocó ${ }^{16}$ do that very well as they describe the art of fishing, the group's worldview, as well as talk about how their world was changed. Differently from the Tupinambá, the Kariri-Xocó, the second People that appears in the book Memories (2012), did not sign with one specific authorial name in their texts. The we is always inserted in the mythical narrative or in other ways of collectivizing their actions and their belonging, in expressions such as: we, grandchildren of a certain mythical warrior, children of $a$ leadership, descents of $a$ founder, belong in this territory. The relationship of the person with his/her ethnic community is conducted by the territory of belonging, which also becomes the recovery of the memory of their ancestors and the place of their ancestry. The self is formed by the confluence of voices of the ancestors, of the spirit of the forests - the enchanted, the constructed worldview, through the political exercise of socially existing. In the indigenous territories that have not been demarcated yet or are still in the process of being demarcated in the northeastern region of Brazil, as is the case of the Kariri-Xocó, writing about oneself is also reproducing the inventory of things. It is about naming facts as a way to record them, making them into memories, apprehending them in time and going back to existing in history, going back to being indigenous.

Oliveira (1998) presents ways of rethinking interpretative possibilities for the facts of the so-called "emergence" of identities, placing in evidence the defense of a historic anthropology that discusses these processes of returning to self, which for the Tupinambá, Tumbalalá, Kariri-Xocó (and so many other) Peoples say of how to become an organized collectivity, formulating one's own identity, establishing mechanisms of return of decision and of representation, and restructuring their cultural shapes (Oliveira, 1998). I add to Oliveira (1998) another need, ethnographic studies that can reflect on the familial relation among those groups, not in the classic sense of the structuralist ethnography, but through an outlook of affection and harmony that unites the group under a collective commonality.

\section{From the Extrospective Autobiographies to the Authorship of the Enchanted}

The relationship between collectivity, myth and enchantments in the way the name of the indigenous itself is constructed is discussed in the work Tradição Pankaré: a Festa do Amaro (Pankaré Tradition: Amaro’s Festival) (2008), a narrative by indigenous authorship which is not part of the collection Indians Through the Eyes of Indians (2008, 2003, 2012), but presents similitudes and differences in the way they remember things as described previously. In the work of Pakaré People's authorship, their self-image was not primarily constructed through remembering the past, but by its summoning, which means, through the words transmitted by the enchanted ones, through the dance of the Spirits of the forest.

\footnotetext{
15 In 1991, in the northeastern region of Brazil, there were 55,853 people self-declared indigenous, according to IBGE (Instituto Brasileiro de Geografia e Estatística-Brazilian Institute of Geography and Statistics). Data from 2010 present a significant growth in the self-declarations as they counted 208,691 indigenous in the same region (Brazil, 2012).

${ }_{16}$ The Kariri-Xocó are located in the region called low São Francisco, the Alagoano county Porto Real do Colégio, in Própria city. Today, they are the gathering of various ethnic groups after centuries of Catechism and villaging. It is valid to mention that the references to the Xocó (or Ciocó) go back to the 18th century. To learn more, check Kariri-Xocó, see from http://pib.socioambiental.org/pt/povo/kariri-xoko/672. Retrieved on 15th September, 2015.
} 
In the work mentioned above, we have the description of Amaro's Festival, as a sacred ritual of this People's history, performed since 1995, when the process of reappropriation of the lands ${ }^{17}$ started at the Pankararé's lands. In their history, narrated in the first plural person, the Pankararé Indians, led by Chief Afonso, gathered to reclaim the village that is called "science of the indians", summoning the enchanted (the spirits of the guardians of nature, named Praiá), so they would give them back, in the "written word" form, the ancestral knowledge about herbs, prayers of the pajé (spiritual doctor), the dances of the Toré ${ }^{18}$, through the consecration of his dance for the healing and protection of the community. The Pankararé, as translators of the teaching about the Praiá, record their history through dance, as a body taken by the enchantments of the spirits of the forest. The photography below, present in the work of the Pankararé's authorship, illustrates the passage of the Praiá through the village during Amaro's Festival (see Figure 3).

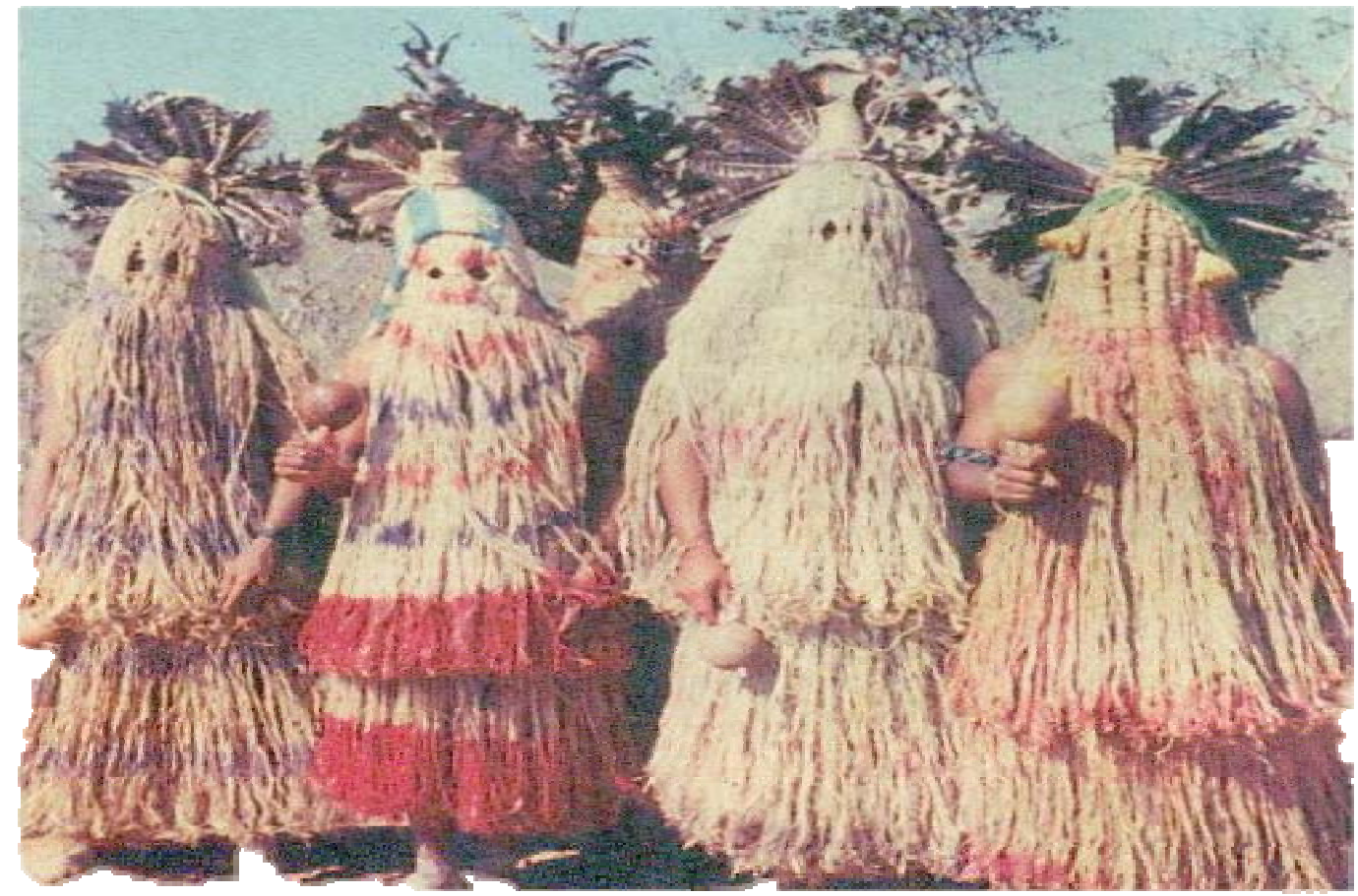

Figure 3. The enchanted: guardians of the forest (Pankararé's People, 2008, p. 20).

At the very beginning of the text introduction, the Pakararé say how the enchantments of the Praiá dances were transmitted by the Pankararu for consecrating the narrative which prays and blesses the Indians as children of the land. About that process of retransmitting knowledge among the indigenous of the northeast, Oliveira (1998) reminds us that, even if the ritualistic practices were transmitted from a Pajéto another, each group will resignify this mixture to reclaim their place as a collectivity according to their own beliefs and interests. The anthropologists refer to the ethnology done by José Arruti, titled O Reencantamento do Mundo: tramahistórica e Arranjos Territoriais Pankararu (The Reenchanting of the World: A Historic Plot and Pankararu's Territorial Arrangements) (1996), to explain how the Pankararu's pajéstaught the communities of

\footnotetext{
17 The Pankararé live at Brejo do Burgo, village located near the Glória County—BA, in the north area of the Ecological Station of Raso de Catarina.

18 The Toré is an indigenous ritual which has different meanings. Its practice and meaning depends on the cultural manifestation of each indigenous people that consecrates it. To learn more, visit from http://cienciaecultura.bvs.br/scielo.php?script=sci_arttext\&pid=S0009-67252008000400018. Retrieved on 16th October, 2015.
} 
relatives of other ethnicities how to do a Praiá, knowing that in each village, be it the Pankararé's People, or the Kanturaré and the Jeripancó, they will build the difference between the Praiá's own home, instituting the gallery of narratives and establishing a specific relation between the oldest enchanted (Arruti, 1996).

This way, every last Saturday of October, the Pankararé prepare themselves to have a festival which leaves early from the Brajo do Brugo and arrives at Amaro's Poró (yard) ${ }^{19}$. The ritual is initiated with prayers to summon the voices of the Enchanted of the forest. When the Praiá appear and start dancing, all the indigenous who watch the dance observe and repeat what is being taught. In the construction of the narrative through dance, who decides what is worth or what is not worth as truth to tell who are the Pankararé is the dancing body of the enchanted, because those, the indigenous believe, do not imitate a character or a singularity, "they do not represent anything, it is the thought-body it is never someone: they are always just symbols” (Badiou, 2002, p. 84). In the paper “A dança como metáfora do pensamento” (Dance as a Metaphor of Thinking), Alan Badiou (2002) suggests, by the dancing feet of Zaratustra, that dance as a metaphor of real thoughts depends on the event happening before the word, for the event is what remains influenced between existing or not-existing (Badiou, 2002, p. 84). In the Pankararé's narrative it is only in possession of the dance that the enchantments appear, and with them, all the self-image of the community. That is the reason why it is important, in the village, to state that the authorship of their narratives belongs to the enchanted:

We only speak about ourselves when we celebrate the invisible things, because who writes everything and tells everything are the enchanted, not us. And the enchanted are everywhere. In every location where one calls out to them, they are present. (Pankararé, 2008, p. 19)

The authorship of those histories of the People only exists by the translation of a ritual practice. There is a collective belief in the sacred as the builder of the name, of the link with the land, of the territory. This way, for the history to be true, meaning, for it to become a collective narrative, it is necessary to listen to what the enchanted said about the Pankararé from before the 19th century, times of the first records about the People. ${ }^{20}$ Who writes, who narrates, who names their narratives first are the enchanted, taken as the voices of the lost ancestry, the voices of the ancestors, which considered through that perspective,

...would be the "old logs" and the current generations "the tips of foliage". That is why when the genealogies were lost in the memory and there are no more palpable links with the old villages, the new villages turn to the "enchanted" to get away from the condition of "mixture" in which they were placed. That is the only way they can reconstruct to themselves the same relationship with their ancestors (their "old log”), maybe rediscovering themselves as "tips of foliage". (Arrudi, 1996, p. 78; as cited in Oliveira, 1998, p. 60)

The narrative where self is presented, diluted in us, name of the People, who writes the text does not define himself/herself as its author, but as its dancer, once it is through the gesture of dancing that it is measured the value of the undeletable truth to whom produces the narratives. That brings up the issue of anonymity of the person and the subtraction of self as the response to the question about who the author of this text is. It is also through extrospection of self, and not by its introspection, how the Pankararé People constructs their own names. When the body of the Praiá dance appears at Amaro's Festival to offer the teachings on the history of

\footnotetext{
19 Amaro's Yard is in the region Raso da Catarina-BA.

20 As a People formed by descents of Pankararu, the historic documents of the Pankararé are present in the records of the Pankararu about the Imperial donation of the colonial land to the religious mission that became the village of their ancestors during the 18th and 19th centuries. The official records about the existence of the Pankararu are only about their extinction, in 1878. To learn more, see from http://pib.socioambiental.org/pt/povo/pankararu/880. Retrieved on 15th September, 2015.
} 
the village, the subject of the only truth vanishes, for the sake of his/her translation, of his/her dance. The dancer, to Badiou (2002, p. 90), suppresses all the dance he/she knows "because he/she takes his/he body as if it had been invented” but the dancers of the Pankararé village are the translators of their own history, returning to it through the language and identity of the spirits of the forest, as the extension of their biographical writings.

\section{Conclusion}

There is considerable subtlety and sophistication in the authorial-us praxis or the plural-self of the indigenous person, present in other literary texts, in interviews, teaching materials, letters, audiovisual materials and in many productions that I have not listed here. The collection Indians Through the Eyes of Indians (2008, 2003, 2012) is a small sample that integrates today the vast field of self-narrative productions of these groups, in which the self is claimed through the collective authorship of the People. Then, one can see the importance in mapping those textualities to reflect on the wide range of processes of formation in the authorial emergence of the indigenous subject, analyzing how this kind of text genre, traditionally linked to the education of a Western individual, is constructed and appropriated in different Ameridian translations.

Either for its collective-self, of for its enchantments, the self-representations of the Tupinambá or the Pankarare, and so many other Peoples mentioned here, present the formation of an autobiographical space that is necessary for recording the ways of existing ethnically and politically. These narratives also present ways of revisiting the relationships between literature, ethnography and politics as types of knowledge that need to circulate and survive before the State, before the media spaces inside/out of schools.

In addition, another of our research itineraries when considering indigenous autobiographies is to discuss the autobiography entry itself, not as a literary genre per se, but also as a field of knowledge, as a methodology and, in that sense, in its own ethnographic ways, putting in evidence the ways and the different supports chosen by the subjects to narrativize their life journeys. Widening this notion also means discussing the formation of a space of authorial indigenous narratives, close to what Arfuch (2002, p. 114) calls biographical space, but wider than the genre, and that encompasses, not the purity of its meaning, but its interactions, the inter-relations, the hybridism of shapes, of its metonymic slides, of its intertextuality.

The formation of this space is also going to happen with the production of individual autobiographies, in other words, with more investment in the proper names of the ones mentioned here. That is why a proper name, the name of the Indian, which is little or never mentioned, both in academic ethnologies and in media discourses or in schools, contributes for its existence as a person implicated in its daily singularities, in its human conflicts, in its individual ways of choosing, of belonging, of conducting his/her own life. I said that not because I believe in the individual beyond his/her collectivity, but specifically to state that there is no such thing as a unified collectivity, essentially formed and harmonically constructed beyond the individual conflicts that mobilize and modify them.

Certainly, part of what was presented as possibility, reading the authorial indigenous productions as autobiographical, still needs further unfolding and comparative analyses to get to the formulation of conclusions about the formation of this space. Therefore, it is possible to say now that, yes, the indigenous in Brazil has decided to record his/her life. The intimate/mythical, collective/singular, historic/enchanted voices of these people are present in a number of textualities that report their lives, but not necessarily in the molds and supports of the biographical or autobiographical genre, which we traditionally have as references. The idea of absence of the indigenous proper name, placed initially as a starting-point question in the introduction of this 
article (and here I agree with Sáez), refer much more to the fact that a place for (auto)biography in literature and history of Brazil has not been created yet.

\section{References}

Arfuch, L. (2002). El espacio biográfico: dilemas de lasubjectividad contemporânea (The biographical space: Dilemas of the contemporary subjectivity). Buenos Aires: Fondo de Cultura Economica de Argentina.

Arruti, J. M. A. (1996). O Reencantamento do Mundo: Trama Histórica e Arranjos Territoriais Pankararu (The re-enchantment of the world: Pankararu's historical plot and territorial arrangements). (Dissertação de Mestrado, PPGAS//MN/UFRJ).

Badiou, A. (2002). Pequeno manual de inestética (A small manual of insthethics). (M. Appenzeller, Trans.). São Paulo: Estação Liberdade.

Brasil. (2012). Os indígenas no senso demográfico 2010: primeiras considerações com base no quesito cor ou raça (The indigenous in the demographic census 2010: First considerations based on the color or race matter). Rio de Janeiro: IBGE.

Cesar, A. L. S. (2011). Lições de Abril: a construção da autoria entre os Pataxó de Coroa Vermelha (April lessons: The construction of authorship among the Pataxó of Red Crown). Salvador: EDUFBA.

Deleuze, G. (2006). Diferença e repetição (Diference and repetition). (R. Machado e L., Trans.). Orlandi. Rio de Janeiro: Graal.

Gerlic, S. (Org.). (2005). Índios na visão dos índios: cantando as culturas indígenas (Indians through the eyes of Indians: Singing other cultures). Salvador: Thydêwá.

Gerlic, S. (Org.). (2008). Índios na visão dos índios: Arco Digital (Indians through the eyes of Indians: Digital bow). Salvador: Thydêwá.

Gerlic, S. (Org.). (2011). Índios na visão dos índios: somos patrimônio (Indians through the eyes of Indians: Were are patrimony). Salvador: Thydêwá.

Gerlic, S. (Org.). (2012). Índios na visão dos índios: cultura viva (Indians through the eyes of Indians: Living culture). Salvador: Thydêwá.

Gerlic, S. (Org.). (2012). Índios na visão dos índios: memória (Indians through the eyes of Indians: Memory). Salvador: Thydêwá.

Lejeune, P. (1975). Le pacte autobiographique (The autobiographical pact). Paris: Seuil.

Lejeune, P. (2013). Da autobiografia ao diário, da Universidade à associação: itinerários de uma pesquisa (From the autobiography to the diary, from the University to the association: A research itinerary). Letras de Hoje, Porto Alegre, v. 48, n. 4. Retrieved from 2015, September 15 http://revistaseletronicas.pucrs.br/ojs/index.php/fale/article/view/1546015

Oliveira, J. P. de. (1998). Uma etnologia dos índios misturados? Situação colonial, territorialização e fluxos culturais (The ethnology of mixed indians? Colonial situation, territorialization and cultural flows). Mana, Rio de Janeiro, v. 4, n. 1. Retrieved from 2015, September 15 http://www.scielo.br/scielo.php?pid=S0104-93131998000100003\&script=sci_arttext

Povo Pankararé. (Org.). (2008). Tradição Pankararé: a festa do Amaro (Pankararé’s tradition: Amaro’s festival). Feira de Santana: GEAP_Projeto de Gestão Etnoambiental Pankararé.

Povo Fulni-Ô. (2001). Índios na visão dos índios: Fulni-ô/PE (Indians through the eyes of Indians: Fulni-ô/PE). Salvador: Thydêwá.

Povo Kariri-Xocó. (2001). Índios na visão dos índios: Kariri-Xocó/AL (Indians through the eyes of Indians: Kariri-Xocó/AL). Salvador: Thydêwá.

Povo Kiriri. (2003). Índios na visão dos índios: Kiriri/BA (Indians through the eyes of Indians: Kiriri/BA). Salvador: Thydêwá.

Povo Pankararu. (2001). Índios na visão dos índios: Pankararú/PE (Indians through the eyes of Indians: Pankararú/PE). Salvador: Thydêwá.

Povo Pataxó Do Prado. (2007). Índios na visão dos índios: Pataxó do Prado (Indians through the eyes of Indians: Pataxó of Prado). Salvador: Thydêwá.

Povo Pataxó Hãhãhãe. (2007). Índios na visão dos índios: Pataxó Hãhãhãe (Indians through the eyes of Indians: Pataxó Hãhãhãe). Salvador: Thydêwá.

Povo Potigura. (2011). Índios na visão dos índios: Potiguara (Indians through the eyes of Indians: Potiguara). Salvador: Thydêwá.

Povo Truká. (2003). Índios na visão dos índios: Truká/PE (Indians through the eyes of Indians: Truká/PE). Salvador: Thydêwá.

Povo Tumbalalá. (2001). Índios na visão dos índios: Tumbalalá/BA (Indians through the eyes of Indians: Tumbalalá/BA). Salvador: Thydêwá. 
Povo Tupinambá. (2003). Índios na visão dos índios: Tupinambá/BA (Indians through the eyes of Indians: Tupinambá/BA). Salvador: Thydêwá.

Povo Tupinambá. (2008). Índios na visão dos índios: Nós Tupinambá/BA (Indians through the eyes of Indians: Us Tupínambá/BA). Salvador: Thydêwá.

Sáez, O. C. (2006 November). Autobiografia e sujeito histórico indígena: considerações preliminares (Indians through the eyes of Indians: preliminar considerations). Novos Estudos CEBRAP, São Paulo, n. 76. Retrieved from 2013, May 12 http://www.scielo.br/scielo.php?script=sci_arttext\&pid=S010133002006000300009\&lng=en\&nrm=is 